\title{
Corporate and country image: a bilateral relationship
}

\author{
Maria-Irina ANA \\ The Bucharest University of Economic Studies, Bucharest, Romania \\ ana.mariairina@yahoo.com \\ Anca-Georgiana ANDREI \\ The Bucharest University of Economic Studies, Bucharest, Romania \\ anca.georgiana.andrei@gmail.com
}

\begin{abstract}
Analyzing this important relationship between corporate image on one side, and country image on the other side is an interesting and actual topic in the context of the increasing level of globalization. Although the subject was approached by place branding scholars and practitioners, there is still a high need for theoretical and empirical research. This documentary article focuses more on the concept of transfer of image, from corporation to country and from country to corporation, but seen from a new perspective, as a Blue Ocean Strategy. The paper will also show the importance of this relation that exists between corporate and country from the image perspective, by given concrete examples withdrawn from relevant literature. At the same time, based on a documentary study, key aspects will be analyzed in order to show the positive aspects generated by the relationship between corporation image and country image. In conclusions, it will be presented how this connection between corporate and country can be one of the best answers to globalization and how the positive transfer of image can be implemented as a Blue Ocean Strategy. The aim of this study is to convince scholars and practitioners to research more on this new topic, because a proactive approach in this field can help increasing tourism and encourage investment and exports.
\end{abstract}

Keywords: blue ocean strategy; globalization; corporate image; nation branding; country image; country of origin.

\section{Introduction}

In recent years, international capital flows recorded a sharp increase, as an answer to globalization. Starting mid '80s, the degree of integration of international financial markets has raised and became more and more obvious, large corporations have invaded the planet and international financial flows forced the economy of every country to extend and limit themselves within the borders of a certain state (Lupan, 2009).

As Anholt (2007) stated, the world became a huge single market and this determined both nations and corporations to focus more on how to gain market share. With more than 191 independent states, the competition between industries increased very much (Kotler and Gartner, 2002). Additionally, globalization made the importance of a place to be more meaningful than before (Robertson, 2001). In these conditions, both countries and corporations started to focus more on improving their image, as a mean of gaining competitive advantage. Another new manner to create market space is shown by the new theory named Blue Ocean Strategy, which aims to transform the competition into something irrelevant by changing the limits of the industry (Kim, Mauborgne, 2005).

In the given context, the main objective of this research is to show how countries and corporations can transfer image using the new theory Blue Ocean Strategy. Concrete examples will be given throughout the article, so the readers to better understand the scope and applicability of the paper

DOI: $10.2478 /$ picbe-2018-0006 


\section{Literature review}

Companies can play the role of ambassadors for their countries and, as Anholt (2003) claimed, they can raise or even change the image of their own country. Even more, Olins (1999) believes that there are cases when a corporate brand can define a country and a country brand can define a corporation. Grahame Dowling $(1994,2001)$ is one of the main authors who studied and recognized the concept of bilateral relationship. He considers that country image can affect companies, industries and brands.

A complex review of the literature reveals that this relationship from the image perspective that exists between corporate and country is under-researched. Empirical studies that explore in detail this subject are almost missing from the branding literature and there is definitely a lot of room for research in this area.

Dowling $(1994 ; 2001)$ is the most prolific author on this subject and he focused a lot his researches on legitimizing this relationship which exists between corporation and country from the image perspective.

There are also other scholars and practitioners who highlighted the positive role that companies might have in building country image. Olins (1999), Van Ham $(2001,2008)$, Anholt (2000, 2002, 2005, 2007), Cerviño (2002), Dinnie (2008) approached this idea in their researches.

Wally Olins (1999) argues that there are many cases when a brand of a corporation cand define a country and when a brand of a country cand define a corporation. At the same time Vanossi (2006) stated that everything that is applied on companies might work on countries, adding that for this to happen a is needed another type of research, more exactly a holistic one.

Companies can play a role of real ambassadors for their countries and, as Anholt $(2000,2003)$ said, they can raise or even change the image of their country. He is focused more on an unidirectional approach showing in his papers how corporations can influence a country image. Same idea is also shared by Dinnie (2008) and van Ham (2001), but van Ham (2008) changed his perspective over the years, considering that there are indeed cases when in the consumers' minds a country is similar to a brand.

Much the same with Olins (1999) and Dowling (1994, 2001), Cerviño (2002) also recognizes that between corporations and nations really exists a bilateral relationship. He proves this by using a model which was conceived by Kim and Chung (1997).

In order to understand the importance of the bilateral relationship that exists between corporations and countries from the image perspective, the documentary research must be completed with the conclusions withdrawn by authors regarding the transfer of image, because without this concept the bilateral relationship studied in this paper remains without a concrete purpose. In conclusions, it will be shown that the positive transfer of image can be approached as a Blue Ocean Strategy.

Marketing practitioners and scholars studied the most image transfer and they focused in areas such as brand extension (e.g. Bhat \& Reddy, 2001; Grime, Diamantopoulos, \&Smith, 2002; Salinas \& Perez, 2009), sponsorship (e.g. Gwinner, 1997; Gwinner \& Eaton, 1999; Smith, 2004) and celebrity endorsement (e.g. Lynch \& Schuler, 1994).

The conclusions of the image transfer literature shows that if the consumers'minds is created this connection between a corporate brand and its country of origin in the 
consumer's mind, many ideas that they have related to the company can be trensfered to the country (Gotsi, Lopez, Andriopoulus, 2011). So, more exactly it highlights that corporate image influences, negative or positive, country image.

\section{Methodology}

The main objective of this paper is to outline the importance of the bilateral relationship between corporate image and country image for the economy in the context of increasing globalization. Given the nature of the study, the most opportune approach was the documentary research, oriented in two directions: one, based on the research of theories developed by relevant authors on this topic, and the other one focused on concrete examples extracted from practice.

Before analyzing the bilateral relationship based on the transfer of image, a short review of the country of origin effect was necessary in order to understand better the idea this paper tries to prove.

\section{COO - Country of Origin Effect}

At present, $\mathrm{COO}$ is not approached anymore only as a place of manufacture. It became a complex concept with multiple dimensions such as country of brand (COB) (Srinivasan, Jain and Sikand, 2004), country of design (COD), country of assembly (COA), and country of parts (COP) (Acharya and Elliott, 2001). Every dimensions has a series of characteristics, but this this article focuses on the transfer of image from corporation to country and from country to corporation.

And in this context it will be taken in considerations the following view, based on the dimensions above: the cultural and the institutional characteristics of a nation can influence the choices at a subconscious level (Noordegaven, Harzing, 2003).

As support of this idea, Ghoshal \& Nohria (1989) view is concludent. They argue that the cognitive directions indicated by top managers are the most important key in order to understand the organizational processes through which corporations adapt themselves to their environment. People who work inside the organization are those who bring the cultural and institutional elements (Kostova \& Roth 2002).

However, a definition of the $\mathrm{COO}$ effect was not accepted at a general level until now. Yet most studies state that consumers in general keep in mind rather stereotypes of countries in terms of image (Bannister and Saunders, 1978; Papadopoulos et al., 1989; Cattin et al., 1982). Han and Terpstra (1988) believe that this means that consumers' evaluations of products and purchase intentions are influenced in this manner, an idea also shared by Bilkey and Nes, 1982.

Nagashima (1977) and Howard (1989) consider that this theory is applied for products in general. At the same time is available but also for very specific brands (Han and Terpstra, 1988; Chao, 1993). This means that it can be applied also for corporations (e.g. Sony is Japan and Japan is Sony (Ollins, 1999)).

In the context of increasing level of globalization, a part of researchers considers that COO effect will be weaker in the future (Samiee, 1994) and another parts argues that it will be stronger and stronger (Papadopoulos et al., 1988; Papadopoulos, 1993; Johansson and Nebenzahl, 1986). 
This paper rallies to the second view, which supports the idea that $\mathrm{COO}$ will be an important element on global markets, which implicitly means that country image will influence corporate image.

\section{Transfer of image from country to corporation}

Bernstein (1984) is a great contributor for the corporate image literature. His book addresses the topic that $\mathrm{COO}$ and industry are factors that can shape the corporation image. Yet, his assumption was unidirectional and neglected the impact that corporate image might have on country image, concept which will be developed in the following sections of this paper.

When an image of a country appears randomly in the world's conscience, it can be built easier (Nicolescu, 2007, 2008, Diaconescu et al, 2007). Complementary to Bernstein's theory, de Vicente (2004) outlines that once a nation has a well-defined image in the consumer's mind, then all the attributes might be transferred to the brands that are the result of their perceptions.

In this direction, Japan is Sony, Switzerland is Swatch, Germany is Mercedes, Sweden is Ikea, Finland is Nokia etc.. But these situations can raise entry barriers that might block the development of markets. The example of Italy is very relevant. The country is well known for fashion and style capital and for this reason, Olivetti, a computer manufacturer had difficulties becoming a successful exporter. Similarly, Hugo Boss, the German fashion brand has to beat the preconception that everything German-made is technical and cold (de Vicente, 2004).

If a country's image is negative, it will be reflected in the perception of the national brands, most often than not even without taking into consideration their quality. On the contrary, when a brand is associated with a country with a positive image, the brand of a product/corporation will be accepted more easily (Jaffe, Nebenzahl, 2001).

Nowadays, the importance of national origin is not very well explained, and at the same time understood by corporations. They act globally, have factories or offices worldwide, cover many markets, but their value set is often perceived as being dominated by a single country (Goodchild, Callow, 2001).

There are a lot of cases when a global brand is associated with the country of origin and for which this association actually represents the core of the brand, having a positive impact on both sides. To support this idea, Levi's - US jeans and Johnny Walker - Scotch whisky (Aaker, 1991) are relevant examples. These two brands are genuine cases of transfer of image from country to corporation and from corporation to country.

At the same time there is also the possibility that brands and nations to be connected in the mind of the final consumer. For example, there is the perception that Microsoft and Coca-Cola are America or that Nokia is Finland (and vice-versa) (van Ham, 2008).

\section{Transfer of image from corporation to country}

Although there is clear evidence regarding the transfer of image from corporation to country, this aspect has been researched even less than the one mentioned above. Anholt (2000) considers that corporations are actually one of the main determinants of a country 
image, and gives the example of companies like Hyundai, Daewoo, Samsung and LG, which have played a key role in building the brand image of Korea.

"On a grand scale, brand names such as Apple, Boeing, Coca-Cola, Disney, Ford, IBM, Kodak, Levis, McDonald's and Xerox have helped shape the image of the USA" (Dowling, 1994:147). This is a similar example like the one described adobe, but giving the example of USA. Additionally, Van Ham (2001) and Cerviño (2002) argue that companies are indeed country-brand ambassadors, while Olins (1999) outlines that countries and corporate are equally transferring their image, Sony being Japan, and Japan being Sony. A strong product brand which is also global such as Sony VCR, can shape the weak country image of a contrty, in this case, Russia. Then as well, a negative country image can deteriorate considerably the brand image of Sony (Nebenzahl and Jaffe, 1996). A concrete case of country which has a strategy of transferring the image of a corporate brand to nation is Estonia. Its strategy is focused on associating itself with Skype and to transform the Skype brand into an important part of its national identity (White, 2012). This thing is obvious also from the efforts of the business community and public remarks by the president of the country (Landler, 2005).

However, the strategy of the company related to brand influences and determines the level of association of a corporate brand with its country of origin (Keller, 1993). So in order to succeed a transfer of image from corporation to country, the relationship must be bilateral.

If in a consumer's mind there is a strong corporate image, a strong brand, then this will influence also his perceptions regarding country image (Gotsi, Lopez, Andriopoulus, 2011). Analouglsy, Smith (2004) who studied image transfer in sponsorship states that the strength of a sponsored brand image has an important impact on image transfer.

\section{Transfer of image as a Blue Ocean Strategy}

The concept "blue ocean" was coined by two innovative professors, W. Chan Kim and Renee Mauborgne in 2005. "Blue Ocean Strategy: How to Create Uncontested Market Space and the Make Competition Irrelevant" (2005) is their book where it is very well explained that this phenomenon defines actually a new market space for an unknown industry or innovation, all this in terms of high potential profits. Blue Ocean strategy is profitable because it relies on attracting a high number of customers, unlocking new demand, while making competition rather irrelevant (Kim and Mauborgne, 2005). Thus, this strategy encourages companies to focus more on alternative ways of finding new customers and less on competitors and current customers (Murray, 2010).

Apple Inc., once a PC maker in a mature and unattractive industry not only achieved sustained profitable growth, but also revitalized the declining consumer electronics industry by making a series of blue ocean strategic moves such as launching iPod, iTunes, iPhone, and iPad. From a blue ocean strategy's perspective, companies seeking profitable growth should not focus their efforts on identifying an existing lucrative market, but should set out to create and capture one. Therefore, in order to avoid or eliminate completely costly competition, companies are advised to innovate and find a blue ocean. Normally, a blue ocean is found where there are no operating firms, giving the business the opportunity to expand without competition. Regarding the topic of this paper, transfer of image equates 
with transfer of customers, more precisely from corporation to country and from country to corporations, meaning that a positive image transfer boosts the brand both sides. Thus, a way of gaining competitive advantage for corporations and countries at the same time on a certain market is to find a blue ocean, which in this case is the innovation through transfer of image.

The literature review covers an important part of the assumptions this paper tries to demonstrate. More exactly, it delineates how the most important authors for this topic consider the existence of the relationship between corporate image and country image, either bilateral or unilateral. However, the purpose of this article is to highlight the importance of transfer of image, considering the bilateral relationship, because the transfer of image is the instrument that can make the difference, for both corporations and nations. Transfer of image implemented as a Blue Ocean Strategy can be a manner of gaining competitive advantage on a global market.

\section{Conclusion}

These days, corporate brands are not used enough as assets in country branding campaigns, and, at the same time, corporations do not focus their communications strategies using as an asset their national origin, preferring to act global.

For less developed and developing countries, the association with a notorious corporate brand could be an important advantage in terms of public diplomacy, national reputation and implicitly country image. A better country image can be translated into higher number of tourists, investments and exports. Wang (2006) considers that country image represents political and economic capital which is reflected in its standing in the international arena, which is a form of soft power (Wang, 20006).

For example, the communication budget of Red Bull exceeds by far the communication budget of Austria, its country of origin (White, 2012). Red Bull does not focus its strategy of increasing the number of customers using the national brand, and neither Austria promotes itself using this brand. Still, if Red Bull and Austria would choose to use transfer of image as a blue ocean, both could gain competitive advantage on a market that they could actually create it through innovation.

Over and above, it is essential to highlight that corporate image can be built faster and easier than country image, but while corporations might disappear or be forgotten, countries stand the test of time, and so does their image. Along with this idea, the transfer of image from corporation to country and from country to corporations, using a blue ocean strategy based on innovation may lead to long-lasting positive effects.

\section{References}

Aaker, D.A. (1991). Managing Brand Equity: Capitalizing on the value of a brand name. New York: Free Press Anholt, S. (2000). The nation as brand., Across the board, Nov/Dec, 22-27.

Anholt, S. (2002). Foreword. Brand Management, 9 (4-5), 229-239.

Anholt, S. (2003). Brand new justice. The upside of global branding. Oxford: ButterworthHeinemann. 
Anholt, S. (2005). Some important distinctions in place branding. Place Branding, 1 (2), 116-121.

Anholt, S. (2007). Competitive identity: The new brand management for nations, cities and regions. Basingstoke, UK: Palgrave Macmillan.

Acharya, C.\& Elliott, G. (2001). An examination of the effects of 'country-of-design' and 'country-of-assembly' on quality perceptions and purchase intentions. Australasian

PICBE | 51 Marketing Journal, 9 (1), 61-75.

Bannister, J.P. \& Saunders J.A. (1978). UK Consumers" attitudes towards imports: The measurement of national stereotype image". European Journal of Marketing, 12 (8), 562-570.

Bernstein, D. (1984). Company image and reality. A critique of corporate communications. Eastbourne: Holt, Rhinehart and Winston.

Bhat, S., \& Reddy, S.K. (2001). The impact of parent brand attribute associations and affect on brand extension evaluation. Journal of Business Research, 53, 111-122.

Bilkey, W. J. \& Nes, E. (1982). Country of origin effects on product evaluations', Journal of International Business Studies, Spring/Summer, 89-99.

Cattin, P., Jolibert, A. \& Lohnes, C. (1982). A cross-culture study of made-in concepts. Journal of International Business Studies, Winter, 131-141.

Cerviño, J. (2002). Marcas internacionales: Co'mo crearlas y gestionarlas. Madrid: Piramide.

Chao, P. (1993). Partitioning country of origin effects: Consumer evaluations of a hybrid product. Journal of International Business Studies, 24 (2), 291-306.

de Vicente, J. (2004). State Branding in the 21st Century - Master Thesis, The Fletcher School, Retrieved from http://www.fletcher.tufts.edu/research/2004/DeVicenteJorge.pdf/

Diaconescu, M., Nicolescu, N \& Pânzaru, F. (2007). The European Identity - between reality and hope. International Conference "Romania within the EU: opportunities, requirements and perspectives", 10-11 May 2007, Sibiu, "Lucian Blaga” University of Sibiu - The Faculty of Economic Studies, Romania, published in Conference Proceedings volume 1, 2007, 135-141, ISBN 978-973-739-428-6, vol.1 ISBN (13) 978-973-739-442-2.

Dinnie, K. (2008). Nation branding. Concepts, issues, practice. Oxford: ButterworthHeinemann.

Dowling, G.R. (1986). Managing your corporate images. Industrial Marketing Management, $15,109-115$.

Dowling, G.R. (1994). Corporate reputations: Strategies for developing the corporate brand. London: Kogan Page.

Dowling, G.R. (2001). Creating corporate reputations: Identity, image and performance. Oxford: Oxford University Press.

Ghoshal, S. \& Nohria, N. (1989). Internal Differentiation within Multinational Corporations. Strategic Management Journal, 10, 1989, 323-337.

Goodchild, J. \& Callow, C. (2001). Brands Visions and Values. John Wiley\& Sons Ltd., Chichester. 
Gotsi, M., Lopez, C. \& Andriopoulos, C. (2011). Building country image through corporate image: exploring the factors that influence the image transfer. Journal of Strategic Marketing 19 (3), 255-272.

Grime, I., Diamantopoulos, A. \& Smith, G. (2002). Consumer evaluations of extensions and their effects on the core brand: Key issues and research propositions. European Journal of Marketing, 36, 1415-1438.

PICBE | 52

Gwinner, K.P. \& Eaton, J. (1999). Building brand image through event sponsorship: The role of image transfer. Journal of Advertising, 28(4), 47-57.

Han, C.M. \& Terpstra, V. (1988). Country-of-origin effects for uni-national and bi-national products. Journal of International Business Studies, 19(2), 235-255.

Howard, D.G. (1989). Understanding how American consumers formulate their attitudes about foreign products. Journal of International Consumer Marketing, 2 (2), 7-24.

Jaffe, E.D. \& Nebenzahl, I.D. (1984). Alternative questionnaire for country image studies. Journal of Marketing Research, 21, 463-471.

Johansson, J.K. \& Nebenzahl, I.D. (1986). Multinational production: Effect on brand value. Journal of International Business Studies, 17(3), 101-126.

Keller, K.L. (1993). Conceptualizing, measuring and managing customer-based brand equity. Journal of Marketing, 57 (January), 1-22.

Kim, W.C \& Mauborgne, R. (2005). Blue Ocean Strategy: From Theory to Practice. California Review Management, 47(3), 105-121.

Kim, C.K. \& Chung, J.Y. (1997). Brand popularity, country image and market share: An empirical study. Journal of International Business Studies, 28(2), 361-386.

Kotler, P. \& Gertner, D. (2002). Country as brand, product, and beyond: A place marketing and brand management perspective, Brand Management, 9(4-5) 249-261.

Kostova, T. \& Roth, K. (2002). Adoption of an Organizational Practice by Subsidiaries of Multinational Corporations: Institutional and Relational Effects, Academy of Management Journal, 45, 2002, 215-233.

Laroche, M., Papadopoulos, N., Heslop, L.A. \& Mourali, M. (2005). The influence of country image structure on consumer evaluations of foreign products', International Marketing Review, 22(1), 96-115.

Lupan, M. (2009). Globalizarea Economiei. Retrieved from Marin, M. (2007, March 1). http://www.seap.usv.ro/ ro/cursuri/ECTS/ECTS_GE.pdf.

Lynch, J., \& Schuler, D. (1994). The matchup effect of spokesperson and product congruence: A schema theory interpretation. Psychology and Marketing, 11, 417445.

Nagashima, A. (1977). A comparative `made in’ product image survey among Japanese businessmen', Journal of Marketing, 41(7), 95-100.

Nicolescu, L., Cojanu, V., Popescu, A.\& Drăghici, A. (2007). Developing country branding: a key factor for international competitiveness, Bucharest, National School of Political Studies and Public Administration, Editura SNSPA, 285-291.

Nicolescu, N. (2008). Imaginea României sub lupă! Branding şi rebranding de țară, Bucuresti, Editura ASE.

DOI: $10.2478 /$ picbe-2018-0006, pp. 45-53, ISSN 2558-9652| Proceedings of the $12^{\text {th }}$ International Conference on Business Excellence 2018 
Noorderhaven, N. G., \& Harzing, A. W. (2003). The "country-of-origin effect" in multinational corporations: Sources, mechanisms and moderating conditions. In Management and International Review (pp. 47-66). Gabler Verlag, Wiesbaden.

Nebenzahl, I.D. \& Jaffe, E.D. (1996). Measuring the joint effect of brand and country image in consumer evaluation of global products. International Marketing Review, 13(4), 522.

Olins, W. (1999). Trading identities: Why countries and companies are taking on each other's roles. London: The Foreign Policy Centre.

Papadopoulos, N., Heslop, L.A. \& Bamossy, G. (1989). International competitiveness of American and Japanese products in Papadopoulos, N. (Ed.) Dimensions of international business (No 2). Ottawa: International Business Study Group, Carleton University.

Papadopoulos, N. \& Heslop, L. (1993). Product-Country Images: Impact and role in International Marketing. New York: The Haworth Press.

Pecotich, A., \& Rosenthal, M. J. (2001). Country of Origin, Brand and Consumer Ethnocentrism. Journal of Global Marketing, 15(2).

Rao, A. R., \& Monroe, K. B. (1989). The Effect of Price, Brand Name and Store Name on Buyers' Perceptions of Product Quality: An Integrative Review. Journal of Marketing Research, 26 (August), 351-357.

Robertson, R. (2001). Globalization theory 2000+: Major Problematics. In: Ritzer, G. and Smart. B. (eds) Handbook of Social Theory. Sage. London. UK.

Salinas, E.M., \& Perez, J.M.P. (2009). Modeling the brand extensions' influence on brand image. Journal of Business Research, 62, 50-60.

Samiee, S. (1994). Customer evaluation of products in a global market. Journal of International Business Studies, 25(3), 579-604.

Smith, G. (2004). Brand image transfer through sponsorship: A consumer learning perspective. Journal of Marketing Management, 20, 457-474.

Srinivasan, N., Jain, S. C. \& Sikand, K. (2004). An experimental study of two dimensions of country-of-origin (manufacturing country and branding country) using intrinsic and extrinsic cues. International Business Review 13(1), 65-82.

van Ham, P. (2001). The rise of the brand state: The postmodern politics of image and reputation. Foreign Affairs, 80(5), 2-6.

van Ham, P. (2008). Place Branding: The State of the Art. The ANNALS of the American Academy of Political and Social Science, 616, 126-149.

Vanossi, P. (2006). Country as Brand: Nation Branding. Retrieved from http://www.affisch.org/weblog/archives/00000187.html

Wang, J. (2006 a). Managing national reputation and international relations in the global era: Public diplomacy revisited. Public Relations Review 32 (2), 91-96.

White, C. (2012). Brands and national image: An exploration of inverse country-of-origin effect. Place Branding and Public Diplomacy, 8(2), 110-118. 